\title{
DITADURA, TORTURA E VIOLÊNCIA DE GÊNERO: ALGUMAS NOTAS SOBRE O ROMANCE A IMPORTÂNCIA DOS TELHADOS, DE VANESSA MOLNAR ${ }^{1}$ \\ DICTATORSHIP, TORTURE AND GENDER VIOLENCE: SOME NOTES ABOUT THE NOVEL A IMPORTÂNCIA DOS TELHADOS, BY VANESSA MOLNAR
}

\section{DOI 10.20873/uft2179-3948.2021v12n2p49-66}

\section{Cristiane da Silva Alves ${ }^{2}$}

\section{[...] a tortura é imensurável tanto para homens} como para mulheres. A tortura dilacera a dignidade humana de ambos os sexos. Mas as mulheres, por serem historicamente discriminadas, sofrem efeitos específicos. Maria Amélia de Almeida Teles

Resumo: A partir do romance A importância dos telhados (2020), de Vanessa Molnar, o artigo busca refletir como as lembranças da protagonista revelam episódios da história pessoal e, também, coletiva. Percebe-se que na ditadura, ainda que homens e mulheres tenham sido aprisionados e torturados, no caso delas as consequências eram agravadas por sua condição de gênero. Embora ficcional, a história da personagem colabora para lançar luz sobre a História nacional e suas chagas. Para embasar as análises, recorre-se às contribuições de Eurídice Figueiredo (2017), Maria Rita Kehl (2010), Jeanne Marie Gagnebin (2006), Maurice Halbwachs (1990) e Márcio Seligmann-Silva (2000), entre outros.

Palavras-chave: Literatura brasileira contemporânea; autoria feminina; ditadura; memória; violência de gênero.

Abstract: Based on the novel A importância dos telhados (2020), by Vanessa Molnar, the article seeks to reflect how the protagonist's memories reveal episodes from personal and, also, collective history. It is noticed that in the dictatorship, although men and women were imprisoned and tortured, in women's case, the consequences were aggravated by their gender condition. Although fictional, the character's story helps to shed light on national history and its wounds. To support the analysis, the contributions of Eurídice Figueiredo (2017), Maria Rita Kehl (2010), Jeanne Marie Gagnebin (2006), Maurice Halbwachs (1990) and Márcio Seligmann-Silva (2000), among others are used.

\footnotetext{
${ }^{1}$ Este trabalho foi realizado com apoio da Coordenação de Aperfeiçoamento de Pessoal de Nível Superior - Brasil (CAPES) - Código 001.

2 Doutora em Letras pela Universidade Federal do Rio Grande do Sul (UFRGS). Bolsista de Pós-Doutorado (PNPD-CAPES/MEC) junto ao Programa de Pós-graduação em Letras da UFRGS, com o projeto de pesquisa "Mulheres velhas: seus lugares e papéis na literatura brasileira do início do século XXI". E-mail: cristianesalves@gmail.com. ORCID: https://orcid.org/0000-0002-1375-1212
} 
Keywords: Contemporary Brazilian Literature; female authorship; dictatorship; memory; gender violence.

\section{Introdução}

Vanessa Molnar, historiadora e Mestre em Estudos Culturais pela Universidade de São Paulo, estreou na literatura com o livro Crônicas de uma tara gentil (2008). Seu segundo livro, A importância dos telhados (2020), foi vencedor do V Prêmio Cepe Nacional de Literatura 2019, na categoria romance. Nele, a história se alinha a outras produções literárias da contemporaneidade, como Mar azul (2012), de Paloma Vidal, e Outros cantos (2016), de Maria Valéria Rezende, apenas para citar alguns exemplos. Em tais romances, as autoras dão voz e destaque para protagonistas femininas que, além da idade avançada, têm em comum um passado marcado por ditaduras, traumas e perdas que, ultrapassando os limites da esfera individual, se relacionam com momentos extremos da história coletiva, que são exteriorizados, reflexionados e se abrem a novas possibilidades de interpretação, a partir de seus relatos.

No romance de Vanessa Molnar, de igual modo, a autora concede a voz a uma sexagenária que, no passado, vivenciou e foi marcada pelas atrocidades da ditadura brasileira. Trata-se de uma velha professora que, no começo da narrativa, toma conhecimento da morte de uma colega e amiga desde a juventude, de quem há tempos se distanciara. A partir de então, a protagonista e narradora é impelida a revolver a memória e recordar acontecimentos que, por décadas, buscou esquecer e que dão início a um manuscrito, através do qual, amalgamando realidade e ficção, ela tenta dar conta do vivido.

À medida que as recordações e anotações vão tomando corpo, sobressaem episódios experienciados por ela e pela amiga, presas e torturadas à época do regime militar no Brasil. As lembranças desse tempo, conforme vêm à tona, escancaram as violações cometidas no país e, igualmente, a impunidade dos agentes criminosos, com consequências que não se encerrariam naquele período. Ao contrário, porque não houve elaboração dos fatos e, também, porque com o benefício da Lei de Anistia (Lei $n^{\circ} 6.683$, de 1979) os crimes praticados ao longo da ditadura não foram apurados, abriu-se caminho para, entre outras coisas, a sua relativização ou negação. Facilitou-se, assim, o ressurgimento, ou antes, a manutenção da truculência, que seguiu ecoando e produzindo vítimas no presente.

Isso posto, busca-se neste artigo refletir como no romance de Molnar, em meio às lembranças, esquecimentos e silenciamentos da protagonista, revelam-se episódios da história pessoal e, ao mesmo tempo, coletiva. Intenta-se, também, analisar como a tortura, ainda que 
sofrida por homens e mulheres presos na ditadura, impactou de maneira acentuada a vida da personagem em decorrência da sua condição de gênero. Pretende-se, de igual modo, examinar como sua história, embora ficcional, lança luz sobre a História nacional e suas chagas.

\section{De quando tudo virou silêncio}

Dividido em sessenta capítulos curtos e numerados, o romance de Molnar é narrado em primeira pessoa e se inicia de forma prosaica, capturando um momento em que a protagonista, instalada na cozinha de sua casa, está preparando um ovo frito e, ao afastar-se rapidamente para verificar algo errado com seus dentes, acaba por deixar queimar o que seria o almoço. A aparente trivialidade com que a narrativa se abre, aos poucos, dá lugar a algumas pistas que permitem-nos vislumbrar o insulamento da personagem, bem como depreender suas motivações para, somente então, compartilhar a história que, por dolorosa e traumática, se mantivera esquecida ao longo dos anos. Bastam alguns parágrafos para constatar que se trata de uma mulher solitária, cujo único filho mora no exterior. Ela não conta sequer com a companhia de um cachorro, pois o seu morrera um mês antes do início da narração.

Além disso, verifica-se que é uma professora de férias, que não sente qualquer ânimo para voltar ao convívio com "estudantes jovens de olhos embaçados ou com velhos ranzinzas que não acreditavam mais no que estavam fazendo" (MOLNAR, 2020, p. 12), descrição que se assemelha ao cenário escolar delineado por Beatriz Bracher em seu romance Não falei (2004) e que, conforme analisa Eurídice Figueiredo (2017, p. 102) “é decepcionante para aqueles que lutaram por um Brasil melhor na década de 1970. À utopia daquela geração sucedeu o vazio e o desamparo". Não é por mero acaso que, depois de anos dedicados ao ensino, a protagonista de A importância dos telhados anseia pelo momento em que, finalmente, se desligará do ofício e poderá pôr em prática alguns planos pessoais: "tinha planejado andar todos os dias e tentar parar de fumar após a aposentadoria, de fazer algumas viagens e me divertir um pouco, mas agora era tarde" (MOLNAR, 2020, p. 93). Um diagnóstico de câncer com metástase, contudo, seria responsável por encurtar as suas expectativas.

Somado a isso, a notícia do falecimento de Ana, amiga de juventude e colega de trabalho, confirma a inevitabilidade da morte e, principalmente, lembra-a de que, em breve, seu passado, seus segredos e suas experiências estarão definitivamente enterrados, cumprindo o almejado por facínoras que, há tempos, operam para promover o esquecimento: "Eu tinha que reagir, fazer alguma coisa, não permitir que eles vencessem - eles, os inimigos que estavam 
tentando apagar a história de pessoas como eu e como Jeremias, a história de Ana e a de tantos outros amigos, mas me sentia impotente" (MOLNAR, 2020, p. 94).

Resta claro que a protagonista não compactua com o silenciamento que os envolvidos nos crimes cometidos durante os anos de chumbo se empenharam em impor ao país, mesmo que, durante longo tempo, ela tenha se calado sobre o que vivenciou à época. Sua impotência para falar, contudo, pode ser compreendida, conforme avança a leitura do romance e toma-se conhecimento do trauma iniciado quando, em meados de 1974, ela e a amiga, então colegas de curso na universidade, foram encarceradas por agentes da repressão e brutalizadas:

[...] só me recordo que havia um cheiro ruim no ar, um cheiro de clausura misturado com abandono, um cheiro de falta de banho, parecido com o da morte, o que se confirmou quando a primeira de nós voltou da sessão de tortura e eu entendi que o medo é uma das armas mais poderosas que podem ser acionadas contra a humanidade. Dali em diante tudo virou silêncio e espanto e eu e a Ana fizemos um pacto forçado de sangue e de hematomas. (MOLNAR, 2020, p. 36-37)

Embora não descreva o episódio em minúcias, a narradora deixa entrever o terror e o desamparo que ambas experienciaram. As marcas físicas são traduzidas por "sangue e hematomas", denunciando os golpes sofridos em seus corpos, enquanto a definição das marcas psicológicas parece impraticável. Acuadas pelo medo, subjugadas pelas atrocidades cometidas pelos torturadores, só lhes restou "silêncio e espanto". Nesse sentido, ao tratar sobre os efeitos da tortura, Maria Rita Kehl (2010, p. 131, grifos da autora) afirma:

A tortura refaz o dualismo corpo/mente, ou corpo/espírito, porque a condição do corpo
entregue ao arbítrio e à crueldade do outro separa o corpo e o sujeito. Sob tortura, o
corpo fica tão assujeitado ao gozo do outro que é como se a "alma" - isso que, no
corpo, pensa, simboliza, ultrapassa os limites da carne pela via das representações -
ficasse à deriva. A fala que representa o sujeito deixa de lhe pertencer, uma vez que o
torturador pode arrancar de sua vítima a palavra que ele quer ouvir, e não a que o
sujeito teria a dizer. Resta ao sujeito preso ao corpo que sofre nas mãos do outro o
silêncio, como última forma do domínio de si, até o limite da morte.

O silêncio, pois, é uma - não raro, a única - reação possível da vítima ante a violação de seu corpo pelo algoz; é um reflexo diante da dor e da sujeição infligida à carne torturada, além de uma tentativa de exercer algum controle sobre si. No caso da protagonista, decorre, particularmente, da aflição e do assombro, sentimentos esses que se ampliariam ao descobrir, depois de ter sido posta em liberdade, que entre os possíveis resultados da violência sofrida, um, em especial, seguiria se prolongando em seu corpo: “A primeira reação que tive foi de negação. Eu ainda tinha alguns semestres pela frente e jogar meus sonhos fora por causa de um fruto da barbárie me pareceu irracional. Concluí que eu não teria forças e que seria melhor fazer um aborto. Não falei nada para a minha família” (MOLNAR, 2020, p. 38). 
Como se pode inferir, seu silêncio acerca dos acontecimentos não diz respeito apenas ao impacto dos abusos sofridos e testemunhados durante a prisão, que, por si só, seriam suficientes para justificar o emudecimento. Decorre, igualmente, da constatação de que as agressões culminaram, para ela, em uma gestação. Se descobrir-se grávida, para muitas mulheres pode ser motivo de alegria, no seu caso, dadas as circunstâncias da concepção, foi um choque, uma continuidade do trauma a que as torturas deram início e que se perpetuaria à medida em que seu corpo fosse modificando-se com o avanço da gravidez. Explica-se, pois, em larga medida, a razão pela qual ela se calou e, da mesma forma, o torpor que a acometeu, freando quaisquer propósitos, resoluções ou atitudes:

Meus planos eram de voltar para a universidade, terminar a graduação e tentar uma
bolsa para fazer pós-graduação fora do país, mas o tempo passava, minha barriga
crescia e eu não conseguia tomar uma decisão, a única coisa que eu conseguia fazer
era estudar francês dia e noite e me entupir de pão, como se uma língua estrangeira
fosse capaz de me colocar em um novo mundo no qual as crianças simplesmente não
pudessem existir ou os ovos não fossem redondos. Decidi dar a criança para adoção,
mas quando ele nasceu, depois de um parto sofrido, não tive coragem e, ao invés disso,
pela primeira vez na vida, pedi para chamarem minha mãe. Apesar de tudo, meu filho
foi meu primeiro amor. (MOLNAR, 2020, p. 38)

A despeito das dúvidas e das dificuldades para levar adiante a gravidez, um novo sentimento seria despertado após o nascimento do bebê. Tomada de afeto, a personagem não teve forças para, conforme havia planejado, dar o filho em adoção. O fortalecimento do vínculo materno, entretanto, impunha o apagamento de tudo o que dizia respeito ao genitor e ao modo como aquela criança fora gerada. O esquecimento, nesse caso, foi um recurso para resistir e conseguir solidificar o amor que, mesmo diante do trauma, desenvolveu pelo filho:

$\mathrm{Eu}$, simplesmente, por uma questão de sobrevivência, apaguei a imagem do pai dele de dentro da minha memória e amputei, metaforicamente, metade do seu DNA, como se essa metade tivesse sido preenchida através de manipulação científica. Eu poderia dizer que ele é adotado, porque nasceu antes do meu casamento, mas seria mentira. Ele nasceu de dentro das minhas entranhas, banhado de sangue como todo bebê e é resultado direto ou indireto tanto das minhas escolhas, das escolhas que fiz quando iniciei minha vida na universidade e me senti livre, quanto da maldade humana que até hoje persegue as mulheres [...]. (MOLNAR, 2020, p. 27)

É oportuno notar, em seu discurso, as evidências de que a violência sofrida, entre outras motivações, envolve a condição de gênero a que a personagem estava sujeita; de acordo com suas palavras, o nascimento do bebê, embora resultado de um estupro, é atribuído às escolhas que ela fez, como se a responsabilidade fosse sua e não da conduta criminosa de alguns agentes do Estado. Além do trauma, portanto, a protagonista também carrega culpa por iniciativas que, conforme se depreende de seu relato, nada mais eram do que a busca por crescimento e 
autonomia, mas que contrariavam os papéis tradicionalmente previstos para as mulheres. Essas, conforme esclarece Marcelo Siqueira Ridenti (1990, p. 114):

ocupavam posições submissas na política e na sociedade brasileira, pelo menos até o
final dos anos 60. A norma era a não participação das mulheres na política, exceto
para reafirmar seus lugares de "mães-esposas-donas-de-casa", como ocorreu com os
movimentos femininos que apoiaram o golpe militar de 1964 .

Uma nova era floresceu, contudo, estimulada pelo advento da pílula anticoncepcional ${ }^{3}$, pela chamada revolução sexual e pelos movimentos feministas que, face a implantação da ditadura, acirraram a resistência e a busca pela liberdade. Nesse contexto, de acordo com Maria Amélia de Almeida Teles (2015, p. 508), "as mulheres foram o segmento da população que mais apresentou mudanças nas suas relações com o trabalho, a família, os homens e também no campo da política". Seria natural, pois, que a protagonista do romance quisesse romper com “o estereótipo da mulher restrita ao espaço privado e doméstico, enquanto mãe, esposa, irmã e dona de casa, que vive em função do mundo masculino" (RIDENTI, 1990, p. 114).

Como outras jovens de sua geração, ela preferiu sair de casa e obter conhecimento, pensar e agir por si mesma, andar pelas ruas, ocupar espaços e garantir direitos que, tradicionalmente, eram reservados aos homens ${ }^{4}$. A personagem queria, entre outras coisas, ter independência, o que parecia viável, desde que ingressara na universidade e fora morar longe dos pais. Ao que tudo indica, porém, isso representava uma afronta ao sistema repressor e machista da época, que se arrogava dominante em relação ao corpo e às ideias, principalmente das mulheres, de quem se esperava uma atitude passiva, de aceitação e domesticidade.

\section{Para além da repressão política, a violência de gênero e seus efeitos}

É sabido que no decorrer da ditadura tanto homens quanto mulheres foram presos e transformados em "corpos destituídos de autonomia, vidas torturáveis e matáveis, expostas aos limites da violência, da crueldade e do extermínio" (TELES, 2013, p. 13). No que diz respeito às mulheres, todavia, as agressões pareciam encerrar, somando-se aos objetivos políticos, um propósito específico: "Docilizar o corpo da mulher para sujeitá-lo, fragilizá-lo, para que ela

\footnotetext{
${ }^{3}$ Cujo comércio "teve início no Brasil em 1962, dois anos após ter sido aprovada nos Estados Unidos" (PEDRO, 2003, p. 242).

${ }^{4}$ Um bom exemplo dessa nova geração de mulheres é retratado ainda no auge da ditadura, no romance As meninas (1973), de Lygia Fagundes Telles. A personagem Lia, opondo-se ao esperado pelos pais, que desejavam que ela tivesse um diploma, noivasse, casasse e enchesse sua casa de netos, prefere sair da Bahia, sua terra natal, e morar em um pensionato de freiras, em São Paulo, onde busca atender aos próprios ideais. Livre e determinada a lutar pelo que acredita, ela tranca a matrícula da faculdade para dedicar-se à militância política.
} 
entendesse sua posição de inferioridade absoluta ao poder instituído, [eram] os objetivos fundamentais da tortura" (COLLING, apud GOLDENBERG, 1997, p. 361).

As crueldades praticadas, portanto, mais do que tentativas de intimidação ou meios para obter informações, eram um modo sádico de subjugar as mulheres, exibindo força e poder sobre seus corpos. Para elas, as vulnerabilidades exploradas pelos agentes se acentuavam, à medida que, diferentemente dos homens, os abusos podiam ocasionar sequelas relacionadas com a sua condição de gênero:

O sistema repressivo não fez distinção entre homens e mulheres. $\mathrm{O}$ que variou foi a forma de tortura. Além das naturais diferenças sexuais da mulher, uma eventual gravidez a torna especialmente vulnerável. Por serem do sexo masculino, os torturadores fizeram da sexualidade feminina objeto especial de suas taras. (ARQUIDIOCESE, 1985, p. 46)

Se o sistema repressivo não fazia distinção para perseguir e prender os/as suspeitos/as de atividades subversivas, fazia-o ao aplicar métodos diferenciados de tortura. No caso das mulheres, especialmente, eram recorrentes as sevícias de cunho sexual, que anulavam a sua dignidade e, não raro, provocavam resultados que os homens jamais viriam a conhecer. Em razão da violência imputada, elas tanto podiam carregar no ventre o fruto dos abusos sofridos, como ocorre com a protagonista de A importância dos telhados, quanto ter arrancados os bebês gerados antes ou no decorrer da prisão: "Para as forças repressivas, as razões de Estado predominavam sobre o direito à vida" (ARQUIDIOCESE, 1985, p. 48).

Assombrá-las com a possibilidade de estupro, seu, de suas filhas ou irmãs, ameaçar de abortamento às mulheres grávidas, ou concorrer para concretizar a perda dos bebês, era uma maneira de abalar as 'subversivas', bem como seus companheiros, amigos e/ou familiares, pressionando-os a colaborarem. Além disso, era um meio de difundir-se o terror, de mostrar autoridade sobre todos e todas que ousassem se insurgir. Aterrorizadas, marcadas, aquelas que, porventura, sobrevivessem, serviam de exemplo para outras que, igualmente, tencionassem desafiar a política de Estado e/ou os padrões socialmente convencionados.

No caso do romance de Molnar, quando a protagonista e sua amiga, diante da brutalidade experienciada, silenciaram, mostrando-se indefesas e amedrontadas, atenderam, em certa medida, ao esperado. O emudecimento de ambas, que pode ter sido entendido pelos algozes como assujeitamento, devolveu-as ao lugar "naturalmente" destinado às mulheres. Elas não foram reintegradas à sociedade sem antes terem sido destruídas, humilhadas e, ao menos aparentemente, não representando mais ameaça ao Estado e/ou à ordem estabelecida:

Finalmente, quando já havíamos perdido as esperanças, fomos soltas. Colegas da universidade se mobilizaram, avisaram as nossas famílias e meu pai arrumou um 
advogado. Talvez o Estado também tenha percebido que não passávamos de meninas bobas e que não valia a pena nos matar. (MOLNAR, 2020, p. 37)

Embora não se saiba por quanto tempo elas permaneceram encarceradas e, tampouco, as razões para terem sido soltas, pode-se atribuir a libertação à sua pouca serventia como informantes, pois, em que pese a sua participação em um grupo de estudos, dedicando-se a leituras marxistas, não há no romance quaisquer indicativos de que tivessem envolvimento em ações mais efetivas contra a ditadura. Por terem sido, talvez, consideradas "meninas bobas", conforme a protagonista supõe, o Estado poupou-lhes, permitindo que sobrevivessem, graça que nem sempre era concedida aos presos.

Para elas, diante dos incontáveis casos de mortos e desaparecidos, silenciar e seguir em frente parecia razoável. É sabido, porém, que quem sofreu torturas guarda marcas que, conquanto nem sempre sejam visíveis, são profundas. $\mathrm{O}$ silêncio era uma frágil defesa para minimizar a dor que, entretanto, não cessaria.

Sua situação, guardadas as devidas proporções, se aproximava a daqueles que sobreviveram às barbáries nazistas e, para dar continuidade à vida, se calaram acerca do passado. Ao abordar as experiências traumáticas do Holocausto e o dilema entre a necessidade e a impossibilidade de representá-las, Márcio Seligmann-Silva (2000) retoma as ideias de Nietzsche sobre o valor do esquecimento e pondera:

Os sobreviventes de Auschwitz convivem com a polaridade - muitas vezes posta de
modo a não deixar escolha - entre o viver e o lembrar. O silenciar alia-se, muitas vezes,
ao viver. A libertação do campo de concentração deve ser compreendida, também, no
seu sentido de libertação de um passado: libertação significa luta pela sobrevivência,
pelo ver-se livre do passado e por liberar esse passado da sua terrível presença e
literalidade. (SELIGMANN-SILVA, 2000, p. 90 , grifo do autor)

Esquecer, nesse caso, não significa negar o ocorrido; trata-se de um mecanismo de resistência, que implica em agarrar-se ao presente e (re)adaptar-se ao mundo e ao que esse (ainda) pode oferecer. Ao mesmo tempo, se todo o empenho dos torturadores se volta para a anulação do sujeito, com práticas que buscam destroçá-lo, cindir seu corpo e sua alma, subjugando-o ao ponto de o torturado preferir, muitas vezes, a morte, talvez se possa considerar que seguir em frente, apesar do dilaceramento, é um ato de insurgência. Sobreviver é confrontar, mesmo que de forma cambaleante, as expectativas aniquiladoras dos algozes.

Para a protagonista de A importância dos telhados, no entanto, jovem, assustada e enfraquecida pela dor e pelas sequelas da tortura, o retorno à vida "normal" parecia inalcançável, sobretudo porque implicava em decisões que não diziam respeito apenas a si mesma. A partir de então, caberia a ela determinar o futuro da criança que carregava no ventre, cuja existência sequer conseguia assimilar, algo que nem o nascimento lograra resolver. Foi 
preciso a chegada e a interferência de sua mãe para que ela começasse a reagir ao torpor, acolhendo, finalmente, o bebê e consolidando a maternidade:

Ela pediu uma bacia, o lavou e sentenciou: "Vai se chamar Ricardo".

Concordei. Era um nome bonito, me lembrava Shakespeare, e para mim, até aquele instante, aquela criança não existia. Nomeá-lo me ajudou a amá-lo, a acreditar que aquele ser pequeno e enrugado existia de fato e que tinha saído de dentro de mim. (MOLNAR, 2020, p. 39)

O amparo da mãe, sua sabedoria, objetividade e fé, foram determinantes para que se estabelecessem os laços afetivos entre a personagem e o filho recém-nascido. Sua autoridade e seu afeto colaboraram fortemente para o restabelecimento da protagonista e para a retomada, na medida do possível, dos planos acadêmicos e profissionais que ela havia traçado e que foram violentamente interrompidos:

Éramos todos jovens e ninguém sabia direito como reagir diante do surgimento inesperado de um filho nascido de forma tão violenta, mas minha mãe sabia, e logo me arrastou para a casa dela, onde me cobriu de carinho e, para minha surpresa, assim que me recuperei, antes de enlouquecer, como achei que aconteceria, em meio a noites mal dormidas, peitos rachados e doloridos, fraldas sujas e um inexplicável sentimento de culpa, ela me mandou de volta para a universidade. (MOLNAR, 2020, p. 40)

A continuidade de sua vida e de seus estudos só foi possível porque, diferentemente de muitos de sua geração, sua mãe era uma pessoa livre de convencionalismos, que acreditava em outros caminhos, para além do lar e do casamento, "destino que a sociedade propõe tradicionalmente à mulher" (BEAUVOIR, 2016, p. 185). Seu abrigo e, sobretudo, a ausência de perguntas e/ou recriminações foram de extrema relevância para atenuar as dores e dificuldades da filha. A seu modo, também se empenhava na luta por um país mais justo e igualitário, diferente da realidade que ela e tantas outras vivenciavam.

É oportuno referir que a opressão das mulheres e os entraves para a seu crescimento pessoal, político e profissional não decorriam apenas dos desmandos do regime ditatorial, mas eram, igualmente, perpetrados ou tolerados por aqueles que deveriam combatê-los. A violência de gênero era favorecida pelo "machismo que reinava na sociedade brasileira no período, a falta de autocrítica dos companheiros e a própria autodesvalorização feminina" (GOLDENBERG, 1997, p. 356), o que é evidenciado no romance quando a narradora conta o que ocorreu com Alice, uma estudante de História que morava com ela à época e engravidou do namorado:

A coitada se apaixonou por ele e, por algum tempo, os dois andaram abraçados, parecendo o casal mais feliz do mundo, até ela engravidar. Ele queria que ela abortasse, mas ela se negou. Todo marxismo do mundo não foi suficiente para fazer frente a uma criação católica e humilde. Sua mãe era uma faxineira que tinha uma fé fervorosa, e após alguns espancamentos ela não aguentou e em um domingo ensolarado fez as malas e partiu. Foi um dia triste. Depois fiquei sabendo que ela teve uma menina, que, evidentemente, criou sozinha. (MOLNAR, 2020, p. 32-33) 
O rapaz, vale notar, era um ex-namorado da protagonista que, certo dia, para contrariedade dela, se aproximara de seu grupo de estudos. Visto que "falava bem e mentia muito, acabou sendo aceito" (MOLNAR, 2020, p. 32) e, apesar da conduta abjeta, seguiu participando e radicalizando as ideias dos estudantes. Seu comportamento em relação à namorada grávida, por óbvio, "foi mal visto e suscitou um debate fraco sobre a condição da mulher e o feminismo, mas como a maioria do grupo era composta por homens eles achavam o tema irrelevante" (MOLNAR, 2020, p. 33).

O episódio deixa claro que, além das violências praticadas pelos agentes da repressão, as mulheres, não raro, também tinham de lidar com as agressões e/ou o descaso dos próprios companheiros, que não tratavam as pautas femininas com a mesma importância conferida a outras demandas. A esse respeito, Ana Maria Colling (2015, p. 376) comenta: "A luta pela causa específica da mulher era considerada inoportuna, inconveniente e divisionista”. Essa foi uma das razões pelas quais a protagonista se apartou do grupo e resolveu, a partir de então, empreender de maneira solitária as suas leituras. $\mathrm{O}$ afastamento, entretanto, não a livrou de ser alvo dos agentes do Estado: "Muitos amigos sumiram e, em setembro de 1974, a polícia invadiu a moradia universitária e eu e a Ana fomos levadas para o Deops ${ }^{5}$ junto com outros jovens apavorados e inocentes" (MOLNAR, 2020, p. 33).

Anos mais tarde, ela teria a confirmação do que, no fundo, sempre soubera: o responsável por sua prisão foi o ex-namorado, o mesmo rapaz que engravidara e espancara a estudante de história com quem ela compartilhara moradia e que, à época, se relacionava com o "monstro". De posse de alguns relatórios do Deops, encontrados em meio a documentos que a neta de Ana lhe entregou após o enterro da avó, a protagonista pôde verificar que foi ele quem delatou o grupo: “[...] para salvar a própria pele. Por questões de segurança, nós usávamos codinomes e ele nos entregou, um a um, para a polícia especializada" (MOLNAR, 2020, p. 63). Enquanto vários estudantes foram empurrados para a prisão, a tortura e, em alguns casos, a morte, o "cachorro"6 saiu ileso.

\section{3 "A gente não pode deixar a história morrer"}

No momento da narração, conforme seria divulgado através dos noticiários, o delator "tinha acabado de assumir a liderança de um partido de extrema direita que ressurgiu com força

\footnotetext{
5 Departamento de Ordem Política e Social.

${ }^{6}$ Alcunha atribuída aos delatores, colaboradores dos serviços de Inteligência, infiltrados nas organizações de esquerda no decorrer da ditadura.
} 
por causa da crise econômica que o país atravessava graças a uma corrupção endêmica da qual quase ninguém se salvou e que ele alegava ser responsabilidade de um comunismo imaginário" (MOLNAR, 2020, p. 63). Para assombro de todos aqueles que pagaram um alto preço por ambicionar um destino diferente e um país melhor, os algozes e seus cúmplices não apenas saíram intocados, como voltaram à tona na atualidade, ocupando cargos de poder e defendendo discursos falaciosos. Grupos conservadores e negacionistas se fortaleceram, mais e mais, angariando espaços e adeptos, "gente capaz de usar a violência, sem nenhum escrúpulo, para defender seus próprios interesses disfarçados de ideais" (MOLNAR, 2020, p. 71), em um visível e alarmante retrocesso para a nação.

É nesse contexto que, não obstante ter preferido, por muitos anos, não dar vazão às lembranças, a protagonista é impulsionada a romper o silêncio. Além do cenário político estarrecedor exibido na TV, o falecimento da amiga e colega, bem como a descoberta do câncer que põe em evidência a sua própria finitude, deflagram um sentimento de urgência, quase uma obrigação de tomar a palavra e escrever a sua história ou, talvez, reinventá-la:

Durante muito tempo optei pelo esquecimento, mas agora que ela tinha partido e que, em breve, eu também iria desaparecer, senti a necessidade de recordar para tentar entender como eu tinha ido parar dentro de um mundo irreconhecível, um mundo que aparentava não ter História, nem tempo, e que estava sendo, aos poucos, engolido por trogloditas, apesar de tantos avanços científicos e de tanta tecnologia inútil, ou talvez eu apenas quisesse reinventar minha vida através de um testemunho, mesmo que inócuo ou falso, para um futuro que talvez nem exista. Quem sabe realmente por que alguém escreve um livro? (MOLNAR, 2020, p. 25-26)

A necessidade de elaborar o que passou e, igualmente, o desejo de restaurar a História, impõe-se, determinando que, antes que seja tarde demais, ela se lance àquele que, talvez, seja seu último ato de resistência, contrapondo o discurso oficial e resgatando, através da escrita, vozes e episódios apagados pelo autoritarismo e/ou pela passagem do tempo. Escrever é uma forma de organizar e, principalmente, de salvaguardar a memória íntima e, ainda, revigorar uma memória coletiva que, perdidos os seus partícipes diretos ou as suas testemunhas, tende a desaparecer. Nesse sentido, Maurice Halbwachs (1990, p. 80-81) ressalta:

Quando a memória de uma sequência de acontecimentos não tem mais por suporte
um grupo, aquele mesmo em que esteve engajada ou que dela suportou as
consequências, que lhe assistiu ou dela recebeu um relato vivo dos primeiros atores e
espectadores, quando ela se dispersa por entre alguns espíritos individuais, perdidos
em novas sociedades para as quais esses fatos não interessam mais porque lhes são
decididamente exteriores, então o único meio de salvar tais lembranças, é fixá-las por
escrito em uma narrativa seguida uma vez que as palavras e os pensamentos morrem,
mas os escritos permanecem.

Ao evocar acontecimentos do passado, externando a violência que recaiu sobre ela e sobre o seu grupo, a protagonista retira o mal das sombras; (re)afirma a sua existência e fixa-a 
através da escrita, de modo que, conhecendo-o ou recordando-o, se possa melhor combatê-lo. Como observa Jeanne Marie Gagnebin (2006, p. 47), "lutar contra o esquecimento e a denegação é também lutar contra a repetição do horror (que, infelizmente, se reproduz constantemente)". Assim sendo, ao retomar o vivido, a personagem confronta o esquecimento coletivo, a denegação que, conforme refere Eurídice Figueiredo (2017, p. 29), "é uma dupla negação: afirma que não aconteceu aquilo que efetivamente ocorreu”.

Apesar de a narrativa mesclar realidade e ficção e se referir a uma trajetória individual - a sua -, ao contar o que vivenciou durante a ditadura, a narradora joga luz sobre a história de outras vítimas do regime militar que, como ela, foram atingidos pela tortura, "com efeitos por tempo indeterminado, talvez longo, talvez pela vida inteira" (GINZBURG, 2010, p. 141). Nesse aspecto, vale notar que pesa sobre as vítimas, ampliando o seu sofrimento, a total impunidade dos algozes. Uma vez que "as práticas infames dos torturadores nunca foram reconhecidas e reparadas publicamente" (KEHL, 2010, p. 126), segue ampliando-se no tempo o sentimento de impotência dos atingidos. Juntamente com a dor, permanece o anseio pelo desagravo que, não se efetivando através da sociedade e dos meios legais, pode produzir, em alguns casos, o desejo de realizar a chamada "justiça com as próprias mãos", perpetuando o ciclo de violência.

Não por mero acaso, a vingança e os seus efeitos nefastos estão presentes no capítulo 54 do romance analisado. Nesse, a protagonista, que só então revela para o leitor o seu nome, dirige-se, pessoalmente, àquela que inspirou uma das personagens de seu manuscrito, "a Maram de verdade, que na vida real, se chamava Mariana, da mesma maneira como eu me chamo Elena, apesar de todos me chamarem de Elle" (MOLNAR, 2020, p. 145). Mariana é uma adolescente, neta de Ana, que, depois de ter lido as páginas que Elle escrevera até então e lhe enviara pelo correio, procura-a para "ouvir sua versão da história. Da história que [ela] fez questão de esquecer e que [a avó] não conseguiu terminar de [...] contar" (MOLNAR, 2020, p. 150). A jovem também aproveita a ocasião para devolver um revólver, encontrado entre os pertences da avó, que acredita pertencer à antiga amiga.

Concordando que a arma era sua, a protagonista narra um episódio obscuro do passado, ocorrido cerca de vinte anos após a prisão e a tortura, envolvendo Ana e Chico, um amigo da faculdade, igualmente vitimado pelos anos de chumbo, e de quem ambas haviam sido amantes: "Eu não me importava porque o que nos unia não era o amor, mas a dor. Tínhamos compartilhado um passado terrível, e o fato de ele ter sido amante de Ana também não me desagradava e, com certeza, teve sua contribuição para aquela escolha - que hoje julgo infeliz" (MOLNAR, 2020, p. 152). Chico, que por meio de alguns contatos acreditava ter descoberto 
tudo sobre a vida de seu torturador, dissera que o homem, por desentender-se com um superior e não lograr a promoção a tenente que lhe haviam prometido, largou o Exército:

\begin{abstract}
Irritado pelo pouco reconhecimento que obteve pelos serviços prestados à Pátria e sem perspectiva de ascender na carreira militar, aproveitou a onda democrática da anistia para pedir baixa, o que antes era bem mais difícil de obter, e abriu um bar em um bairro da periferia de São Paulo, onde vivia tranquilo com a esposa e dois filhos, como se nunca tivesse cometido nenhum crime na vida. (MOLNAR, 2020, p. 153)
\end{abstract}

Saber que seu algoz seguira sem qualquer punição e, não obstante, levava uma vida pacata, ao lado da família, deixou-o transtornado: "Para ele, a essência da questão ainda não estava resolvida. Não bastava anistia ou democracia. Era preciso a realização de uma vingança, uma vingança pessoal que fosse capaz de enviar aquele homem direto para o inferno!" (MOLNAR, 2020, p. 153). Embora não compartilhasse do desejo de fazer o torturador "pagar na mesma moeda" (MOLNAR, 2020, p. 153), Elle acabou revelando a história de seu filho, o que serviu de justificativa para o amante seguir em frente com seu plano.

Após convencê-la a entregar o revólver que pertencera ao marido, de quem ela havia se divorciado, Chico contatou dois amigos que também haviam sido torturados e, juntos, foram até o bar investigar. Em que pese o "suspeito" ter negado veementemente que havia sido militar, o amante de Elle não se convenceu e decidiu buscá-la para ajudar a identificar o tal homem: "Tentei argumentar que não me lembrava do rosto dele, mas não adiantou. O Chico insistiu que eu deveria vê-lo mesmo assim, e acabei cedendo" (MOLNAR, 2020, p. 155). A partir de então, entre a sua irresolução e a obsessão de Chico, essa última ganharia força, encaminhando a história para um hediondo desfecho:

O Chico saiu com um colega e sacou a arma. O homem achou que fosse um assalto, entregou a carteira, disse que não tinha mais dinheiro, mas que o que ele tinha eles podiam levar, depois suplicou que o deixassem em paz, porque tinha uma família para criar, mas eles ignoraram suas súplicas, o encapuzaram e colocaram no carro. Eu não esperava por aquilo, não aguentei, comecei a chorar e pedi para me deixarem em casa. O Chico ficou furioso, gritou, me mandou calar a boca, estava transtornado, e, aterrorizada, obedeci. (MOLNAR, 2020, p. 155-156)

Diante disso, Elle lembra que saíra correndo do carro e, no dia seguinte, acordara muito tarde, sem saber o que havia sucedido. Ela e o amante nunca mais se viram, mas cerca de um mês depois do dia fatídico, Ana chamou-a para um café e contou que ele havia se suicidado:

Fiquei chocada.

Ela quis me devolver a arma, mas não aceitei.

- Guarde com você - respondi seca porque tinha acabado de descobrir que eles nunca tinham deixado de ser amantes.

Era tudo um plano, e eu fazia parte dele, e era por isso que aquela arma tinha ido parar ali. (MOLNAR, 2020, p. 156) 
Com a morte de Chico e a descoberta de que ele e Ana haviam tramado, envolvendo Elle de maneira traiçoeira em seus planos de vingança, a amizade das duas mulheres foi abalada. Apesar de algumas tentativas de entendimento, elas acabaram por se afastar. Como se pode notar, as consequências da ditadura e da tortura, mesmo décadas mais tarde, permaneciam repercutindo e, direta ou indiretamente, dilacerando, arruinando vidas e comprometendo afetos. Velhas feridas voltavam a sangrar, enquanto outras, novas e não menos dolorosas, se abriam. Ao narrar e escrever a respeito, contudo, Elle dá início ao seu processo de cura.

Nesse sentido, revela-se igualmente importante o recebimento de uma carta que a amiga lhe deixou e que foi entregue por Mariana. Seu conteúdo, entre outras coisas, esclarece algumas questões que, por mal resolvidas, ensejaram o rompimento da amizade de longa data. Ana confirma que a vingança fora um plano seu, que estava tão obcecada quanto Chico. Ao mesmo tempo, nega que ele tenha utilizado a arma de Elle para se suicidar (sua morte foi por envenenamento) e admite que, afinal, não valeu a pena fazerem "justiça com as próprias mãos", pois, assim agindo, "ao invés de banir, banalizamos o mal" (MOLNAR, 2020, p. 158). Ademais, a revanche não surtiu o efeito esperado, posto que não diminuiu a sua dor, e, como resultado, acrescentou-lhes o medo: "O medo, Elle, o medo de termos matado a pessoa errada, de termos cometido um crime, esse medo não nos abandona, não é?” (MOLNAR, 2020, p. 158).

A carta de Ana, embora não tenha o condão de desfazer o que se passou, colabora, de algum modo, para que a protagonista se liberte da amargura que, até então, carregara. A amiga, afinal, não pretendera magoá-la; ao contrário, acreditava, equivocadamente, que agira em seu benefício, vingando-a por todo o sofrimento que compartilharam, pelos meses de aflição que acompanhara enquanto a barriga de Elle crescia, abrigando o fruto das sevícias a que fora submetida na prisão. O crime planejado por Ana foi uma tentativa vã de buscar justiça, ainda que por vias tortas. Ao fim e ao cabo, ela fora vencida pelo mal: "Nós todos fomos vítimas de um sistema político violento, nosso país foi forjado na violência e até hoje é muito difícil escapar disso" (MOLNAR, 2020, p. 159). Assim como Chico, ela pensara, erroneamente, que morto o algoz, seu padecimento e o dos demais desapareceria, mas só o que obteve foi um amontoado de perdas.

Talvez por isso, para evitar que esse saldo trágico se perpetuasse, resolveu contar para a neta o que se passou ou, ao menos, o que foi possível revelar e, da mesma forma, sugere na carta que a antiga amiga assim proceda em relação ao filho. É movida por esse desejo que, afinal, Elle decide expor brevemente a Ricardo a sua tortura, assunto sobre o qual nunca haviam conversado. Entre outras razões, ela sente que deve "contar a verdade para evitar que ele viesse 
a se tornar um fascista, ou simplesmente um ignorante egoísta, como estava acontecendo com uma parte da classe média no mundo" (MOLNAR, 2020, p. 171). Seu relato, além de um resgate do passado, ou antes, uma tentativa de ressignificação desse, é uma aposta no futuro, uma esperança de que, conhecendo a sua versão da história e tendo a possibilidade de refletir sobre o que aconteceu, as futuras gerações possam resistir à repetição da barbárie.

O final do romance, a propósito, reafirma o desejo e o esforço da protagonista para estancar o ciclo de violência. A caminho do aeroporto, ela se depara com o homem que denunciou seu grupo para o Deops, levando-os à prisão e à tortura. $\mathrm{O}$ delator estava em cima de um carro de som, vociferando em direção a um grupo de professores e estudantes que protestavam contra o governo e os cortes no orçamento da Educação.

Por um golpe do destino, Elle carregava na bolsa o antigo revólver do ex-marido: "A intenção era parar no caminho e jogá-la no rio, ou deixá-la na lixeira do aeroporto" (MOLNAR, 2020, p. 171). A situação que, por si só era tensa, corria o risco de agravar-se: "Nossos olhares se encontraram surpresos com o inusitado da situação. Ficamos frente a frente como nos filmes. Tive certeza de que ele me reconheceu. Abri a bolsa, era só destravar a arma, mas não tive coragem. Já havia ódio demais em todos os lugares” (MOLNAR, 2020, p. 172).

Em que pese a "oportunidade", ela, que lera a carta deixada por Ana, sabia que a vingança não trouxera qualquer conforto aos amigos; ao contrário, apenas ampliou dores e perdas, comprovando que não se vence o mal pagando-o na mesma moeda. Assim, mesmo diante da possibilidade de eliminar aquele homem desprezível e cruel, ela preferiu seguir em frente, se desapegar. A despeito dos horrores que ele e seus pares praticaram no passado e que seguiam incitando na atualidade, presenciar o protesto dos professores e estudantes dera a Elle esperança; o país resistiria, como tantos outros, afinal, resistiram.

\section{Considerações finais}

Se é compreensível a necessidade de as vítimas de traumas silenciarem para seguir vivendo, também se percebe que seu emudecimento colabora para que a História oficial siga sendo difundida, privilegiando a versão dos algozes. Esses, como se sabe, beneficiaram-se em nosso país com a Lei da Anistia (Lei $n^{\circ}$ 6.683) que, em 1979, sob o pretexto de viabilizar a reconciliação, permitiu que os crimes perpetrados durante os anos de chumbo não fossem apurados. Assim, uma vez que "nada se constitui em obstáculo à tênue linha de demarcação entre anistia e amnésia" (RICCEUR, 2007, p. 462), facilitou-se o esquecimento coletivo e, como 
consequência, propiciou-se a manutenção e até o agravamento da truculência, ou, antes, "a naturalização da violência como grave sintoma social no Brasil” (KEHL, 2010, p. 124).

A ficção, nesse caso, pode ser considerada como uma espécie de arma contra o alheamento, atuando não propriamente para vingar, mas para pôr a nu essa face nefasta de nossa História, reagindo, na medida do possível, ao que Bernardo Kucinski (2014, p. 12) tão acertadamente definiu como o "mal de Alzheimer nacional". No que diz respeito ao romance de Vanessa Molnar, ao narrar a própria história, enfrentando dores, ausências e não ditos, a protagonista não apenas cuida de entender o passado, mas, ainda, de empreender aquela que seria, provavelmente, a sua última luta, o ato final contra "a banalização do mal que tomou conta da nossa história recente" (MOLNAR, 2020, p. 35), desvelando o que alguns remanescentes da ditadura, em especial aqueles diretamente implicados em violações aos direitos humanos, se esforçaram para silenciar. Ao retomar a sua trajetória, a narradora personifica outras tantas que, como ela, foram/são brutalizadas, tendo seus direitos e sua liberdade postos em xeque.

Seu relato, em certa medida, resgata histórias e vozes daquelas que pereceram e seguem perecendo, vitimadas pela repressão e pelo machismo que ainda pairam, assombrosamente, entre nós. Essa narração, embora dolorosa, é necessária, pois, como bem lembra Gagnebin (2006, p. 57), “somente a transmissão simbólica, assumida apesar e por causa do sofrimento indizível, somente essa retomada reflexiva do passado pode nos ajudar a não repeti-lo infinitamente, mas a ousar esboçar uma outra história, a inventar o presente".

O romance, conforme reabre feridas da personagem e, ao mesmo tempo, da nação, permite lembrar que o autoritarismo, a barbárie e, principalmente, o ódio contra as mulheres e as tentativas de controle sobre seus corpos e suas decisões, não cessaram; ao contrário, a violência de gênero é tema atual, o que resta comprovado à medida em que assistimos aos noticiários e nos deparamos, diariamente, com novos episódios de feminicídio.

Além disso, não é demais referir que uma parcela reacionária da sociedade, com frequência, responsabiliza as vítimas pelo desfecho fatal, especulando sobre sua conduta e sobre o que teriam dito, feito ou vestido para "merecer" o trágico fim. A questão, contudo, carece de revisão, indagando-se o que ditadores, torturadores e feminicidas têm em comum e em que medida o abrandamento ou a ausência de punição, bem como de memória, favorece-os.

\section{Referências}


ARQUIDIOCESE DE SÃO PAULO. Brasil: nunca mais. Prefácio de Dom Paulo Evaristo Arns. Petrópolis, RJ: Vozes, 1985.

BEAUVOIR, Simone de. O segundo sexo: a experiência vivida, vol. 2. Trad. Sérgio Milliet. $3^{\text {a }}$ ed. Rio de Janeiro: Nova Fronteira, 2016.

BRACHER, Beatriz. Não falei. São Paulo: Editora 34, 2004.

BRASIL. Lei $\mathrm{n}^{\mathrm{o}}$ 6.683, de 28 de agosto de 1979. Disponível em: http://www.planalto.gov.br/ccivil_03/leis/16683.htm. Acesso em: 09 jun. 2021.

COLLING, Ana Maria. 50 anos da ditadura no Brasil: questões feministas e de gênero. OPSIS, v. $15, \quad$ n. 2, p. 370-383, 19 dez. 2015. Disponível em: https://www.revistas.ufg.br/Opsis/article/view/33836/20058. Acesso em 15 fev. 2021.

FIGUEIREDO, Eurídice. A literatura como arquivo da ditadura brasileira. Rio de Janeiro: 7 Letras, 2017.

GAGNEBIN, Jeanne Marie. Lembrar escrever esquecer. São Paulo: Ed. 34, 2006.

GINZBURG, Jaime. Escritas da tortura. In: TELES, Edson; SAFATLE, Vladimir (org.). O que resta da ditadura: a exceção brasileira. São Paulo: Boitempo, 2010, p.133-149.

GOLDENBERG, Mirian. Mulheres e Militantes. Revista Estudos Feministas. Instituto de Estudos de Gênero da UFSC: Florianópolis, v.5 n², 1997, p. 349-364. Disponível em: http://www.jstor.org/stable/43904552. Acesso em: 1 jul. 2021.

HALBWACHS, Maurice. A memória coletiva. São Paulo: Editora Revista dos Tribunais LTDA, 1990.

KEHL, Maria Rita. Tortura e sintoma social. In: TELES, Edson; SAFATLE, Vladimir (org.). O que resta da ditadura: a exceção brasileira. São Paulo: Boitempo, 2010, p.123-132.

KUCINSKI, Bernardo. K. Relato de uma busca. São Paulo: Cosac Naify, 2014.

MOLNAR, Vanessa. A importância dos telhados. Recife: Cepe, 2020.

PEDRO, Joana Maria. A experiência com contraceptivos no Brasil: uma questão de geração. Revista Brasileira de História [online]. v. 23, n. 45, 2003, p. 239-260. Disponível em: https://doi.org/10.1590/S0102-01882003000100010. Acesso em 13 jul. 2021.

RIDENTI, Marcelo Siqueira. As mulheres na política brasileira: os anos de chumbo. Tempo Social, [S. 1.], v. 2, n. 2, 1990, p. 113-128. DOI: 10.1590/ts.v2i2.84806. Disponível em: https://www.revistas.usp.br/ts/article/view/84806. Acesso em: 1 jul. 2021.

RICCEUR, Paul. A memória, a história, o esquecimento. Campinas: Editora da Unicamp, 2007. 
SELIGMANN-SILVA, Márcio. A história como trauma. In: NESTROVSKI, Arthur; SELIGMANN-SILVA, Márcio (orgs.). Catástrofe e representação: ensaios. São Paulo: Escuta, 2000, p. 73-98.

TELES, Janaina de Almeida. Apresentação: Ditadura e repressão no Brasil e na Argentina: paralelos e distinções. In: CALVEIRO, Pilar. Poder e Desaparecimento. Boitempo: São Paulo, 2013, p. 7-18.

TELES, Maria Amélia de Almeida. A construção da memória e da verdade numa perspectiva de gênero. Revista Direito $G V$ [online]. v. 11, n. 2, 2015, p. 505-522. Disponível em: https://doi.org/10.1590/1808-2432201522. Acesso em: 13 jul. 2021.

TELLES, Lygia Fagundes. As meninas. São Paulo: Círculo do livro, [1985?].

Recebido em 02 de agosto de 2021 Aceito em 27 de setembro de 2021 